\title{
A profile of visitors to Brazil Amazon
} Protected Areas: Anavilhanas National Park (Amazonas) and Tapajós National Forest (Pará)

Perfil de Visitantes em Áreas Protegidas da Amazônia: Parque Nacional de Anavilhanas (Amazonas) e Floresta Nacional do Tapajós (Pará)

Robert Clyde Burns - West Virginia University - Robert.Burns@mail.wvu.edu Lidiane Castro Gregory - West Virginia University - Lidianecas@gmail.com Jasmine Cardozo Moreira - Universidade Estadual de Ponta Grossa-jasmine@vepg.br

\section{RESUMO}

O propósito deste estudo foi identificar um perfil de visitantes em dois locais turísticos e unidades de conservação na Bacia Amazônica brasileira: Floresta Nacional do Tapajós (Pará) e Parque Nacional de Anavilhanas (Amazonas). Uma pesquisa in loco foi feita nas duas áreas. O total de questionários utilizados nesta análise foi de 2512 (1255 em Tapajós e 1257 em Anavilhanas). O foco principal do estudo foi entender melhor o perfil dos visitantes, incluindo a demografia social, as características da viagem, bem como as percepções dos visitantes, suas motivações e satisfação de suas experiências recreativas. Os dados coletados oferecem uma fonte importante de informações para os gestores das áreas protegidas, para que eles possam entender melhor as necessidades recreativas e a capacidade atual de uso em ambas as áreas protegidas. Um dos objetivos deste estudo foi reunir dados para entender o fluxo atual de visitantes na Amazônia, enfocando suas características específicas. Esse tipo de informação é crucial para a gestão do uso público e o desenvolvimento do turismo em áreas protegidas. A equipe do projeto é grata ao Serviço Florestal dos EUA - Programas Internacionais (USFS - IP), Agência dos EUA para O Desenvolvimento Internacional (USAID) e ao Instituto Nacional de Alimentos e Agricultura (NIFA) do USDA que tornaram este estudo possível. Os autores também agradecem ao Instituto Chico Mendes (ICMBio), à Floresta Nacional do Tapajós, à equipe do Parque Nacional de Anavilhanas e aos membros da comunidade local que coletaram dados e apoiaram esta pesquisa. 
Palavras-chave: Monitoramento da visitação, perfil, Uso público, Unidades de Conservação.

\section{ABSTRACT}

The purpose of this study was to identify the profile of visitors at two touristic settings and protected areas in the Brazilian Amazon Basin: Tapajós National Forest (Pará) and Anavilhanas National Park (Amazonas). An onsite survey was conducted across the two areas. The total of number of usable data points from the two areas of study used in this paper is 2512 surveys (1255 at Tapajós and 1257 at Anavilhanas). The primary focus of the study was to better understand the social demographics, trip characteristics, as well as visitors' perceptions, their motivations, and satisfaction with their recreational experiences. The data collected offers an important source of information for managers so that they may better understand the recreational needs and current capacity for use at both protected areas. One of the aims of this study was to gather data to understand the current flow of visitors in the Amazon by focusing on their specific characteristics. This type of information is crucial for managing public use and developing tourism in protected areas. The project team is grateful to the US Forest Service-International Programs (USFS-IP), US Agency for International Development (USAID), and the USDA National Institute of Food and Agriculture (NIFA) who made this study possible. The authors are also grateful to the Instituto Chico Mendes (ICMBio), Tapajós National Forest, Anavilhanas National Park team and local community members who have collected data and supported this research.

Keywords: Visitor Monitoring, profile, Public Use, Conservation Units.

\section{INTRODUCTION}

Tourism and recreation in protected areas has been increasing worldwide, and with that comes increased visitor expectations (Boley, McGhee \& Hammett, 2017; Lee \& Jan, 2019). There are a number of reasons that have led people to find alternative options of leisure and entertainment in nature. A recent study in Austria compiled literature and findings related to the benefits of woodlands/nature on human health and well-being (Cervinka et al., 2014). According to these studies, contact with nature positively affects an individual's health by providing relief from stress and attention fatigue, 
encouraging exercise, and facilitating social contacts. A recent article in National Geographic addressed the choice of protected areas as a site for recreational activities, demonstrating the relevance of this theme and the overall public interest in it (Williams, 2016).

This paper presents the results of visitor use data collection at Anavilhanas National Park and Tapajós National Forest, in Brazil. The primary focus of the study was to better understand the profile of visitors, including social demographics, trip characteristics, as well as visitors' perceptions, their motivations, and satisfaction of their recreational experiences. The methodology applied for data collection was one of the first of its kind to be implemented at ICMBio's units in the Amazon. Face-to-face interviews were conducted with electronic tablets and the survey days were stratified across weekends, weekdays and holidays.

The study highlights the role of data collection in support of tourism development at two touristic settings in the Brazilian Amazon Basin; the Tapajós National Forest (TNF) and the Anavilhanas National Park (ANP). The Tapajós National Forest is located in the state of Pará, approximately 1,400 km from the State capital (Belém). The TNF is a primary location for those interested in learning about the Brazilian Amazon rainforest, and also attracts local visitors with its white sandy beaches and tropical weather. The Anavilhanas National Park is located in Novo Airão, a small community located about $200 \mathrm{~km}$ from Manaus, the capital of the state of Amazonas. Manaus is known as the gateway city for the Amazon region, with an international airport bringing thousands of tourists weekly. Manaus is highly urbanized and offers a wide range of attractions. The town of Novo Airão hosts 400 hundred fluvial islands within the limits of the ANP; and is among the most popular destinations in the area.

Tourism, when conducted appropriately, can provide needed income to remote and traditional communities. This paper explains that is needed to make management decisions related to tourism infrastructure and services. 
Implementing a methodology for monitoring public use in conservation units involves engagement of different parties, from federal agency, community, and stakeholders.

This study found a lack of information regarding visitation in conservation units in the Amazon region. Therefore, it is unknown as to what extent managers of this areas have been accessing science based information on the decision making process. This way, one of objectives of this study was to gather data to understand the current flow of visitors in the Amazon by focusing on their specific characteristics. This type of information is crucial for managing public use and developing tourism in protected areas.

\section{PROTECTED AREAS IN BRAZIL: AN OVERVIEW}

The history of protected areas in Brazil initiated during Brazil's colonial period (1530-1889) (Medeiros, 2006). However, the first National Park in Brazil (Itatiaia National Park) was created only in 1937. The Itatiaia National Park was created under Brazil's first regulation on parks and forests, the 1934 Forest Code (Drummond, 2016). Over the course of several years, Brazil's protected areas system was loosely structured and lacked technical and scientific criteria (Pádua, 1978). According to Drummond, "In the mid-1970s Brazil had created only eighteen parks - small, underfunded, understaffed, unevenly distributed among regions and biomes, plotted mostly in settled areas, and scantily visited" (2016, p.220). The 1979 Plan represented a milestone for recreation in the history of Brazilian protected areas. This plan was a result of a five-year collaborative effort of two organizations, the IBDF (a government agency) and FBCN - Brazilian Foundation for Nature Conservation - (an NGO) after extensive research on Brazil's resources and knowledge acquisition of global park policies. The 1979 Plan enabled proposals for the creation of other types of protected areas other than National Forests and National Parks 
based on technical and scientific criteria. Over time, a total of twelve categories were examined and implemented.

The combination of events in the years after the 1979 plan provided the basis for the federal legislation of the entire system of protected areas. The SNUC (National System of Conservation Units) legislation from 2000 establishes criteria and standards for the creation, implementation, and management of Conservations Units (Lei N. 9.985, 2000). The National System of Conservations Units is anchored to the following fragment of Brazil's Constitution: "It is the right for all to have an ecologically balanced environment, for a healthy quality of life and common public use, which binds the public power and the community to the duty to defend it and preserve it for present and future generations" (Constituição da República Federativa do Brasil, 1988, p.36 translated). This legislation requires the State to defend the rights of all Brazilian citizens by allowing the creation of areas with the goal of conserving biodiversity (Garcia, 2015).

To reinforce and support the development work, the Brazilian Federal Agency Chico Mendes Institute for Biodiversity and Conservation (ICMBio) was created in 2007. ICMBio, overseen by the Ministry of Environment, is responsible for the management of federal conservation units. The early years in the history of National Parks in Brazil saw no central agency responsible for the park system, and the parks were managed under several separate institutions. This lack of central administration certainly impacted the development of these areas in terms of policies, management, allocation of resources, and primarily, visitation (Souza, 2016).

After the formation of the National System of Conservation Units (SNUC) the number of protected areas in Brazil doubled (Medeiros \& Young, 2011). The SNUC is a set of standards for the creation and management of federal, state, and municipal conservation units. The Brazilian National System of Conservation Units (SNUC) first divides protected areas in two groups with distinct characteristics; integral protection conservation units and sustainable 
use conservations units. Within these two types are twelve use categories. This paper focuses on two of these categories, National Park and National Forests. National Parks fall under the integral protection group, which aims to preserve natural ecosystems of great ecological relevance and scenic beauty. This category emphasizes scientific research, environmental education and interpretation, recreation in contact with nature and ecological tourism (Lei N. 9.985, 2000, translated). The SNUC legislation, in essence, suggests that National Parks are and should always be open to public visitation. However, budgetary problems and lack of management and visitation plans have resulted in many parks in Brazil remain inaccessible to visitors.

National Forests are considered as sustainable use conservation units that focus on the sustainable use of forestry resources and scientific research (Lei N. 9.985, 2000, translated). In this category, public use visitation is permitted, conditioned upon the regulations established on the management plan of the conservation units. Also, the sustainable use of the forest should benefit the traditional population residents of the area. Park visitation data from 2015 reveals that the most visited conservation units are the National Parks and National Forests categories (90\%) (Souza, 2016).

Brazil is a forested country (54.4\% of its territory) and represents the second largest forested area in the world (Serviço Florestal Brasileiro, 2013). There has been a recent push to ensure that conservation units in Brazil exist not only to conserve nature, but also to address the increasing demand of visitors. Data released from the Federal Agency (ICMBio, 2016) reveals a $238 \%$ increase in visitation since 2006; with the total number of visitors rising from 2.99 million to 7.14 million in 2015. The most frequently-visited Brazilian conservation units are located in the Southeast and Southern regions of Brazil; the Tijuca and the Iguaçu National Parks. The Iguaçu National Park received a total of 1,788,922 in 2017 (ICMBio, 2018).

Recently, conservation units in Brazil have served not only to conserve nature, but also to address the increasing demand of visitors. The Amazon 
region of Brazil, similar to other conservation units, attracts a variety of visitors, with increasing potential for economic development through touristic activities. A study conducted by the Economic Research Institute Foundation (FIPE) estimates that in 2006 the Amazon Region received approximately 400,000 visitors, and that the average flow of tourists to the region is about 2 million visitors per year (Rodrigues de Jesus, 2010). Although recent research shows the broad relevance of the Amazon Region, further studies related to tourism and recreation focused on protected areas are needed. Burns \& Moreira (2013) pointed out that the concept of public use management in the Amazon region of Brazil is relatively new to forest managers. In 2014 the USFS - International Programs and the Chico Mendes Institute for biodiversity and conservation (ICMBio) - Brazilian agency responsible for protected areas - initiated a partnership for the development of tourism in conservation units in this region. To fill the gap on information regarding the type of use and visitor, a systematic visitor monitoring approach was piloted in two different areas in the Amazon.

Burns and Moreira (2017) emphasized the relevance of understanding who is visiting the protected areas in the Amazon and their perceptions of the visit. They also suggested that this understanding will set the basis for providing the best possible outdoor recreation opportunities while minimizing negative environmental impacts. The number of visitor monitoring studies in Brazil, and particularly in the Amazon region, is still quite limited.

The Amazon region alone accounts for nearly half of the federal lands in Brazil. Although the number changes frequently, there were 334 conservation units at the federal, state and private level just within the Amazon Region (Ministério do Meio Ambiente, 2018). This number fluctuates annually, as various units enter the protected area system or move from one category to another. The majority of the conservation units are located in the Amazon rainforest, where tourism visitation remains quite low when compared to other regions of Brazil. Castro, Souza and Thapa (2015) attributed the low 
visitation to a lack of opportunities and infrastructural development, combined with budgetary constraints and absence of societal support. In a recent study, Burns and Moreira (2013) compared Brazilian protected areas with those in the United States and Central Europe. Their findings reveal that the creation and management of protected areas in Brazil is based on an eco-centric view (as opposed to an anthropocentric view), with little attention given to the role of recreation in these areas. This may also explain why Brazil's protected areas, although well suited for recreation, still receive significantly fewer visitors when compared to visitation of protected areas within the US. This disparate distribution in visitation within protected areas in Brazil can lead to negative consequences, such as environmental impacts and congestion.

Although the number of visitors is low, much of the tourism/recreation use occurs in just a few areas in the protected areas. Management implications regarding infrastructure, environmental monitoring, and visitor monitoring should also be taken into account. Over the past few years, Brazil has been undergoing a slow transition toward viewing its protected areas in a more anthropocentric manner, with an increased emphasis on visitor use (Burns \& Moreira, 2013).

In terms of managing conservation units, Brazil was specifically influenced by the US through the diffusion of two movements, preservationist and conservationist. These two terms are often treated as synonymous due to their relation to protection. However, their differences are found in the way protection is performed or achieved. The preservationist represented by John Muir approaches protection as protection of nature from use (White, 1985). The natural resource should be subject to minimum or non-human intervention; this way, protected areas would become isolated islands from economic and social reality (Pimentel \& Magro, 2011).

On the other hand, conservationism for Pinchot, a primary influencer in early environmental issues, means protection through proper use of nature 
(White, 1985). The natural resources should be used in a rational manner, meaning that human use should be regulated for the use of resources by present and future generations and waste prevention. Even though the management of protected areas in Brazil presents traits of both concepts in its core system, the preservationist appears to be more prevalent, therefore diverging from the US.

Another important aspect of the history of Brazil's protected areas that diverges from the US is related to maintaining the livelihood of native/traditional populations living in areas designated as national parks or protected areas. This was a concern noted by the International Union for Conservation of Nature (IUCN) which was later incorporated into the creation of Brazil's own protected areas' system.

It is important to highlight that tourism in protected areas, if well planned, can leverage economy of small populations living in and within the limits of these areas. There is also an opportunity to promote conservation and awareness through increasing visitor's sense of stewardship.

\section{MATERIAL AND METHODS}

Data for this study were collected over a two-year period from May 2015 through May 2017. The surveys were conducted across every weekdays, weekends and different holidays. A face-to-face survey method was used, including both quantitative and qualitative questions.

Through the use of electronic tablets and the DroidSurvey application, data were collected and uploaded via Wi-Fi to an online platform, then downloaded into an SPSS (Statistical Packages for the Social Sciences) database for further analyses. Besides facilitating the management of the data and streamlining data processing, this digital approach diminishes the 
amount of printed material. Frequencies, valid percentages, and means were used to describe the sample. For comparative analyzes between the two areas independent samples tests and Pearson's Chi-square tests were conducted.

A total of six well-trained interviewers were involved in the data collection process, three for each site. Some of the advantages of face-toface interviews include the possibility of further explanation of and repetition of questions if needed in order to overcome any language barriers (Berg \& Lune, 2004).

In the Tapajós, data was collected in the three gateway locations to the Forest (São Domigos, Maguari, and Jamaraquá). At the Anavilhanas, interviews were conducted in the area known as Flutuante dos Botos, an entry and exit point of tours to the Park. In both locations, visitors were interviewed at the end of their experience in the park/forest. The average time to answer the survey was 8 minutes. A total of 2512 completed surveys were used in this analysis (1255 at Tapajós and 1257 at Anavilhanas). This research was conducted with SISBIO approval and authorization under the number 42819, dated March 2015.

\section{Survey Instrument}

The survey instrument used in this research was designed and implemented by the WVU Recreation Research team in the Amazon. The survey instrument followed some of the NVUM (United States National Visitor Use Monitoring) guidelines regarding its structure and type of questions. NVUM can be defined as a permanent sampling system for assessing visitor's characteristics, measuring use, as well as satisfaction with the National Forest systems of recreation opportunities (English, Kocis, Zarnoch \& Arnold, 2002). This framework is well known among US parks and forest managers. For this study's purpose, 24 questions were selected. These questions included 
demographic information, trip characteristics, satisfaction items and motivation. The survey instrument was originally created in English and then translated and made available in three other languages including Portuguese, Spanish, German and French.

In the sociodemographic set of questions, visitors were asked about gender, age, country of residence (if Brazilians, state and city of origin), and education level. Group characteristics included questions regarding the number of adults and children per group, type of group, and group composition. For trip characteristics, visitors responded to questions about trip planning, length of the visit, frequency of which they visit the area, transportation mode, activities participated in, and primary activity. The satisfaction portion of the survey included two questions, the first one assessing the visitors' overall satisfaction with the area. The second rated the quality of specific items such as facilities, safety and security, trail condition, cleanliness of the area, interpretation, and access roads. Visitors had a not applicable option for items that did not apply to their recreation experience. A 5-point Likert scale (1 = poor, 5 = excellent) (Likert, 1932) was used to measure overall satisfaction as well as satisfaction level for each item. The main motivation of the recreationists visiting the area was assessed through a single selection type of question.

\section{Study area}

The Tapajós National Forest (TNF) was named as a protected area in 1974, and is the second oldest national forest in Pará state. The area consists of approximately 550,000 hectares and has as its boundaries the Tapajós river on the western border, and an important trans-Amazon road (BR 163, Cuiabá - Santarém highway), to the east. The municipality of Belterra marks its limits on the north and the municipality of Rurópolis its limits south. The area encompasses the municipalities of Placas, Rurópolis, Belterra, and Aveiro. As other Conservation Units in the Amazon, the TNF originated as a counterparty 
to a government occupation project that supported farming families to migrate to the Amazon. This project included construction of "colonizationhighways." In the surrounding areas of these projects and highways Conservation Units were created as a mechanism for protection of resources (Medeiros, 2006; Peres \& Terborgh 1995).

Access to the Tapajós National Forest is possible via boat or car from the city of Santarém, which is the nearest airport and dock. Fluvial access takes 5-6 hours to one of the first three inhabited communities. The distance by land is approximately $50 \mathrm{~km}$ via BR 163. The wet season worsens road conditions and depending on the season, the trip can take between 1.5-2.5 hours. The TNF presents a varied landscape that includes $160 \mathrm{~km}$ of freshwater beach, native forest, lakes, swamps, dryland woods, hills, grasslands, and native acai berry plantations. Although there is an extreme difference between the dry and wet seasons, recreation activities are available through the whole year. Opportunities for hiking, swimming, watching wildlife, canoeing, learning about local culture through visiting the communities, and buying sustainable products are some of the activities offered to the tourists regardless of the season. Aside from the setting attributes, the TNF is characterized by the diversity of its inhabitants. More than 4000 traditional dwellers, distributed across 21 communities, make their living in the TNF.

Tourism in the Tapajós National Forest is well-established, however it was only in 1993 that regulations regarding recreation were established (e.g. permits, charging access fees). One of the early Brazil Amazon studies, an ecotourism study (Tanner, Thomas, Sills, \& Silva, 1997) can be considered the first one seeking to identify the profile of potential tourists to the Tapajós National Forest. The primary aim of that work was to gather information for the development of an ecotourism plan. The findings of this study were used to justify investments in tourism in the following years. It also subsidized the public use section of the management plan of 2004. As mentioned earlier, the two pillars of National Forests in Brazil are sustainable multiple use of forest 
resources and scientific research, recreation activities are only permitted if noted in the management plan. Despite development efforts and investments, tourism on the TNF continues to be rustic in nature. The facilities are simply redários (hammock lounges), built as an extension of a resident's house with an offering of home-cooked meal services.

The Anavilhanas National Park (ANP) is located in Amazonas state, approximately $200 \mathrm{~km}$ from the capital city of Manaus. The park consists of $350.469,00$ hectares, and is bounded to the north and east by the Rio Negro. Novo Airão is the main point of access to the park, either by land or water.

The park was originally created in 1981 as an Ecological Station, for the purpose of protecting Anavilhanas fluvial archipelago in the Rio Negro. Public use was not allowed until 2008, when the area was re-categorized as a National Park. One of the greatest differences between a National Park and an Ecological Station is their openness to public visitation. The goals of Ecological Stations are nature preservation and scientific research, and public visitation is not allowed unless it is noted in the management plan or upon specific regulation (Lei N. 9.985, 2000). This ordinance allows for visitation, and to minimize the eventual impacts of visitation on the natural environment.

The Anavilhanas National Park is renowned for having one of the largest archipelagos in the world. The 400 islands provide unique scenery that attracts visitors from a variety of local, national and international locations. The landscape of the area consists of dense rainforest, dryland woods, woodlands, campinarana igapó (backwater-flooded Amazonian forest), and beaches. As opposed to the Tapajós National Forest, there are no communities living within the Park. During the dry season, the activities available include swimming at the beaches and hiking. During the wet season, visitors have the chance to go on aquatic trails through the flooded forest. In both seasons, visitors can participate in wildlife-watching tours, 
scenic small airplane flights, shopping for local products, and interact with the Amazonian dolphins.

Dolphin viewing has been a popular recreational activity since at least 1998, but only established as an official park activity in 2010 (Romagnoli, 2009). Strategies for visitor management of tourism with dolphins were presented by Vidal, Santos, Jesus, Alves and Chaves (2017), including rules and guidelines to reduce the risk of accidents and to increase the benefits of tourism at the Park. Visitors are now strictly regulated, and must observe an educational briefing about the dolphins before they visit and observe the animals being fed. Only staff members are allowed to feed the animals and the number of visitors and time limits are strictly adhered to. Tourists can touch the animals, take pictures, and even interact with the dolphins in the water via a submersible platform.

Alves, Machado, Vilani, Vidal, Andriolo and Azevedo (2013) evaluated this touristic activity involving the interaction between the Amazonian dolphins (Inia geoffrensis) and humans, based on the conditioning through artificial feeding, using the Anavilhanas National Park as case study. They observed that the activity has significantly increased over recent years. Romagnoli's (2009) research suggested that the floating dolphin station (Flutuante dos Botos) receives an average of 250 visitors per week. The visit to the Flutuante is included on cruise ships and hotel tours, however the experience is open to any type of visitor independent of a tourism package.

It should be mentioned that the Amazonian dolphins or botos are of cultural importance to the people of the Amazon. In Amazon mythology, a young woman who becomes pregnant out of wedlock is said to have been seduced by the botos, who comes out of the river at night and turns into a handsome man. This mythology is celebrated in all Rio Negro towns with traditional dancing and music. 


\section{RESULTS}

The profile of the respondents consisted of highly educated Brazilians, as nearly two-thirds (65.4\%) reported having a undergrad or graduate degree, with an average age of 39 years. The ratio of females was slightly higher $(53.3 \%)$ than male visitors, and nearly two-thirds of the visitors held a college degree or higher. The vast majority of the visitors were from Brazil (83.5\%), who originated from the states of Amazonas (27.6\%), Pará (22.3\%), (the states in which the study was conducted) and São Paulo (22.1\%). In this sense, proximity along with travel costs might have an influence on the high number of in-state visitors (Kinker, 2002). Although not geographically close to the study areas the state of São Paulo was well represented among visitors in the Amazon. São Paulo is the most populated state of Brazil, is as place of origin for domestic trips in Brazil, and is among the states of Brazil with highest income (Jesus, 2010; Santos, Ramos \& Rey-Maquieira, 2014).

The average number of adults in a group was five (mean= 4.93) and for the groups with children, the average number of children per group was two (mean= 2.25). Nearly three-fourths of the respondents reported no children in their group. Of those with children, family groups were the most popular and corresponded to over one-fourth $(28.0 \%)$ of the interviewees followed by groups of friends (22.3\%). Couples and mixed groups composed of family and friends were also commonly represented with $19.1 \%$ and $13.5 \%$ of the respondents respectively. A small percentage $(6.9 \%)$ of the visitors reported traveling alone. Altogether, commercial groups, education, and organized groups comprised $11.9 \%$ of the groups visiting the areas.

The results show that over one-third of the visitors $(40.8 \%)$ made their decision to visit the areas either on the same day of the visit or spent between 2-3 days planning their trip. Less than one-fifth of respondents (16.0\%) said they spent 4 to 14 days planning. Over one-third (30.2\%) of the respondent's answers concentrated on 15 days to 3 months of trip planning. 
The vast majority (84.6\%) of respondents were first-time visitors while only $15.4 \%$ were repeat visitors. Of those returning to the areas, the mean for the year of their first visit was 2009. Over half of the visits $(53.7 \%)$ were day visits with a length of stay of nearly 6 hours (mean= 5.55). Overnight visits represented $46.3 \%$ of the sample and the average length of stay of those were four days.

Among the top three modes of transportation used by the visitors, over one-third (42.4\%) of respondents opted for land transportation, while onefourth (27.6\%) used water vehicles - i.e. speedboat and sailboat. Other transportation modes reported by the visitors included rental cars and public or private buses.

Respondents participated in a range of activities during their visit to the areas; The most popular activity was swimming (57.9\%), followed by viewing wildlife (53\%), and having a Iunch/picnic (50.3\%). Other activities such as hiking (49.7\%), boating/canoeing (48.1\%), and buying crafts (31.3\%) were also common activities among the recreationists. In this question visitors were allowed to pick as many activities as they had participated in.

In terms of the primary reason for the visit, nearly half $(48.4 \%)$ of the respondents selected an option connected to a personal characteristic, such as: I enjoy nature. Almost one- fourth (24.7\%) opted for an option associated to a characteristic of the place Good place to experience culture. A number of people visited the areas for social reasons such as spending time with family and friends (10.1\%). Less common reasons for visiting were those related to personal connections with the place, activity driven reasons, or proximity.

The survey also assessed the level of recreationist satisfaction. Over half of the respondents (66.7\%) rated their visit as either excellent or perfect. A group of nearly one-third (30.1\%) evaluated their satisfaction level as either good or very good. Only a few respondents (3.2\%) rated their visit as poor or 
fair. On a 6-point scale (poor= 1 and perfect= 6), the mean rate for overall satisfaction was 4.80 .

In addition to the overall satisfaction question, recreationists were asked to evaluate the quality of single items of their trip. In this question the option not applicable was available and the percentages were excluded from the mean. The item trail condition was rated with the highest mean (4.16) followed by safety and security (4.04). The items access roads and environmental interpretation were rated with the lowest means, (3.36) and (3.51), respectively. The domains cleanliness of area and facilities were equally rated (mean= 3.83 ) with medium satisfaction level.

\section{Some diferences between the visitors in both areas}

Cross tabulation, chi-square, and independent samples t-tests were conducted in order to analyze the overall significant differences between recreationists of the Tapajós National Forest and Anavilhanas National Park. The questions selected for analyses pertained to sociodemographic, reason for visit and satisfaction. Findings were reported in tables containing valid percentages, Person's Chi-Square values, and degrees of freedom, and $\dagger$ values.

Table 1 shows the results of comparison of the variable country of origin. A cross-tabulation analysis through the use of Person's Chi-Square test shows that there was no significant difference regarding the percentage of national and international visitors recreating in the two locations $\left(x^{2}=1.346, \mathrm{df}=1, \mathrm{p}>\right.$ .05). The Tapajós National Forest and the Anavilhanas National Park received a similar range of national and international visitors as confirmed in the table below.

Table 1: Results of Comparison of Sociodemographic / Countries

\begin{tabular}{|c|c|c|c|}
\hline & $\begin{array}{c}\text { Tapajós } \\
\%\end{array}$ & $\begin{array}{c}\text { Anavilhanas } \\
\%\end{array}$ & \\
\hline Country & & & $x^{2}=1.346$ \\
\hline
\end{tabular}




\begin{tabular}{lccc}
\cline { 2 - 2 } Brazil & 84.3 & 82.6 & $\mathrm{df}=1$ \\
Foreign country & 15.7 & 17.4 & $\mathrm{p}=.246$ \\
\hline
\end{tabular}

Source: Authors

The table 2 shows the results of an analysis of the primary reason for visiting the Forest/Park. No significant differences were found $\left(x^{2}=17.343\right.$; $d f=$ $5 ; p>.05)$. The majority of both Tapajós and Anavilhanas visitors reported the same primary reasons for visiting the areas. The options I enjoy nature, and It is a good place to experience culture had the highest percentage of respondents. The other options were also reported with similar percentages for both areas.

Table 2: Results of Comparison of Reason for Visit

\begin{tabular}{lccc}
\hline & $\begin{array}{c}\text { Tapajós } \\
\%\end{array}$ & $\begin{array}{c}\text { Anavilhanas } \\
\%\end{array}$ & \\
\hline $\begin{array}{l}\text { Primary reason for } \\
\text { visit }\end{array}$ & & & \\
I enjoy nature. & 48.6 & 25.6 & \\
$\begin{array}{l}\text { Good place to } \\
\text { experience culture. }\end{array}$ & 23.9 & 10.6 & $\mathrm{~d}=17.343$ \\
Want to spend time & 9.5 & & $\mathrm{p}=.004$ \\
$\begin{array}{l}\text { with family/friends. } \\
\text { I like the place itself. }\end{array}$ & 8.8 & 9.9 & \\
It is a good place & 6.4 & 5.0 & \\
to do the outdoor & & & \\
$\begin{array}{l}\text { activities that I like. } \\
\text { It is close home. }\end{array}$ & 2.7 & $<1.0$ & \\
\hline
\end{tabular}

Source: Authors

For analyzing differences in trip satisfaction across both locations (Table 3), an independent sample t-test was applied to compare the means. A significant difference was noted ( $t=-10.393 ; p<.001)$, with Tapajós visitors more likely to report the highest level (excellent) of satisfaction with their trip; conversely, Anavilhanas visitors were more likely to rate the overall level of satisfaction with their trip as very good or excellent. 
Table 3: Results of Comparison of Satisfaction

\begin{tabular}{|c|c|c|c|c|}
\hline & $\begin{array}{c}\text { Tapajós } \\
\%\end{array}$ & & $\begin{array}{c}\text { Anavilhanas } \\
\%\end{array}$ & \\
\hline \multicolumn{5}{|c|}{ Overall satisfaction } \\
\hline Poor & $<1.0$ & & 2.3 & \\
\hline Fair & 1.3 & & 2.4 & \\
\hline Good & 6.4 & & 13.2 & \\
\hline Very good & 16.3 & & 24.0 & \\
\hline Excellent & 35.6 & & 34.8 & \\
\hline \multirow[t]{2}{*}{ Perfect } & 39.5 & & 23.4 & \\
\hline & 5.04 & Mean & 4.57 & $t=-10.393^{* * *}$ \\
\hline
\end{tabular}

Source: Authors

Further analyses of satisfaction focused on single items of the respondents' trip and their level of satisfaction. An independent sample t-test was conducted to compare the means for each item from both locations.

Table 4: Results of Comparison of Satisfaction (Continued)

\begin{tabular}{lccc}
\hline & Tapajós & Anavilhanas & \\
& & Mean & \\
\hline Quality Domain & & & \\
Cleanliness of area & 3.91 & 3.76 & $\dagger=-3.775^{* * *}$ \\
Safety and security & 4.16 & 4.06 & $\dagger=-6.562^{* * *}$ \\
Trail condition & 4.23 & 3.69 & $\dagger=-3.848^{* * *}$ \\
Facilities & 3.96 & 3.17 & $\dagger=-6.374^{* * *}$ \\
Access roads & 3.55 & 3.38 & $\dagger=-4.737^{* * *}$ \\
Environmental & 3.63 & & \\
interpretation & & &
\end{tabular}

As seen in Table 4, significant differences were found among all the items. Tapajós visitors reported to be more satisfied ( $M=3.91$; $S D=958$ ) with the item cleanliness of area than Anavilhanas visitors $(M=3.76$; $S D=990)(t=-$ 3.775; $p<.001)$. Anavilhanas respondents were more likely to feel unsafe ( $M=$ 3.91; $S D=941)$ while recreating in the area than Tapajós visitors $(M=416 ; S D=$ 828) $(t=-6.562 ; \mathrm{p}<.001)$. For the respondents that participated in hiking activities, Tapajós visitors indicated higher level of satisfaction $(M=4.23 ; S D=$ 
840) with the trail conditions than Anavilhanas visitors ( $M=4,06$; $S D=892)(t=-$ 3.848; $p<.001$ ). In terms of facilities, Tapajós visitors, again, indicated higher level of satisfaction $(M=3.96$; $S D=884)$ than the Anavilhanas ones $(M=3.69$; $S D=1.025)(t=-6.374 ; p<.001)$. The item access roads received the lowest mean in both areas $(M=3.55, S D=969 ; M=3.17, S D=1.275)$, however, Anavilhanas respondents indicated lower levels of satisfaction than Tapajós respondents $(\dagger=-8.002 ; \mathrm{p}<.001)$. The last item listed, environmental interpretation, was also low rated in both areas $(M=3.63, S D=1.085 ; M=3.38$, $S D=1.264)$ yet, Tapajós respondents were higher satisfied than respondents from Anavilhanas $(\dagger=-4.737 ; p<.001)$.

\section{DISCUSSION}

Tourism has the potential to have a positive and lasting impact on rural and remote communities-when done appropriately. Tourism development has been used as a means to empower community in innumerable settings around the world members (Lew \& McKercher, 2002; Jamal \& Getz, 1995; Joppe, 1996). In its simplest form tourism should provide benefits-not only to the tourist, but to the community. Eagles (2016) suggests the community member seeks (and hopefully receives) benefits from the tourist and tourism, and the tourist receives a personal benefit from the experience. Achieving this is not easy. As Van Niekerk suggested (2014) tourism planning is often fragmented, unplanned and generally chaotic. In this effort we chose to focus on one setting over a two-year period. This allowed us to avoid some of the pitfalls outlined and explained in previous research and planning efforts. When well managed, visitation can expand the spectrum of opportunities for conservation (Boza 1993; Castro et al. 2015).

Visitor monitoring studies are important planning and organization tools when planning for visitation in protected areas (Burns \& Robinson, 2017; 
Marion \& Farrel, 2002). Visitor monitoring studies are still relatively rare in Brazil and especially in the Amazon region. This study sought to analyze data from recreational users in two protected areas in the Amazon to understand demographics, trip and group characteristics, and reason for visit among the population. This information was provided to managers to make critical management decisions related to the different types of visitors (Arnberger, Ebenberger, Schneider, Cottrell, Schlveter, Ruschkowski, Venette, Snyder \& Gobster, 2018; Burns \& Graefe, 2007).

One of the aims of this study was to gather data to understand the current flow of visitors in the Amazon by zooming into their specific characteristics. Knowing that this type of information is crucial for managing public use and developing tourism in protected areas; this section focus only on the pieces of this study that pose practical implications for managers.

As mentioned in other studies and reinforced in this one, incorporating visitor monitoring programs into the management of the Tapajós National Forest and Anavilhanas National Park is crucial. Implementing a methodology for monitoring public use in conservation units involves engagement of different parties, from federal agency, community, and stakeholders. Strengthening partnerships is fundamental for gaining extra help on data collection and analysis-and visitor monitoring is useless unless the data collected are applied to management decisions.

This study found a lack of information regarding visitation in conservation units in the Amazon region. Therefore, it is unknown as to what extent managers of this areas have been accessing science based information on the decision making process. This can directly affect the efficiency of regulations regarding public use. It is important to point out that these regulations set the roles for public use. Thus, management decisions have a direct effect on tourism development.

Designing marketing plans focused on visitor profiles, and aligned to the conservation unit's management plan, is important for the growth of 
tourism in the Amazon. In both conservation units visitors were mostly from the areas near the park/forest. The existence of regional tourism is evident and can be solidified through actions promoting the area within the region. One way to do this is supporting special promotions targeting in-state visitors so they can become frequent visitors. These types of visitors are responsible for continuous support to the local economy (Tiefenbacher, Day \& Walton, 2000).

In both locations, managers should ensure a safe environment for the practice of outdoor recreation activities in the areas, mainly at the ANP where safety and security was rated lower compared to the TNF. Also, when planning infrastructure managers should be mindful to the type of groups visiting the area and its specific needs. Due to the existing demand for high educated visitors in both areas, the development of educational activities targeting this public is recommended. Additionally, interpretive signs could be incorporated as either complementary or main components of educational activities. Especially at ANP, informative signage including information such as limits of the park is recommended.

For the Anavilhanas location, development of basic infrastructure to house recreational activities inside the Park is suggested. Currently tourism concentrates in only one area and the activity is viewing wildlife, specifically the dolphins. Families and couples are the most prevalent type of group visiting the park, activities and tourism packages targeting these groups would enhance the quality of their visit.

The Tapajós site has an advantage of already having some infrastructure due to the communities that live in the area. However, this infrastructure may need be supplemented to better attend to the needs of the visitors. Results of this study also shows that the cultural offerings of the traditional communities could be explored as a component of tourism. The National Forest has a potential for ecotourism and this should be taken into account by the managers (Tanner et al., 1997; Souza 2016). 
The community's perceptions about tourism is as important as visitor's perceptions about its experience. Collective involvement is crucial for short and long term results in tourism. The Tapajós National Forest should seek more benefits of the flow of tourists already visiting Alter do Chão while developing its own reputation as a destination.

There are new opportunities that could be explored in future research. There is a need for cross comparative studies in outdoor recreation. Furthermore, aligned with this work, other studies should be conducted in different conservations units to identify the visitor's profile in Brazil. It is also important to explore what other variables could be influencing the results. Previous research has suggested that crowding can influence satisfaction, however this seems not to be the case in Brazil. Other variables may include social issues, such as poverty, and a simple lack of awareness of the role that protected areas can play in peoples' lives.

Making use of the information from this study and other data to implement management changes will be the greatest challenge. Resource managers at most other conservation units have no data on visitor use, so using social science data is not common. Another challenge is in attracting visitors to Amazon settings. While some visitation occurs, many Brazilians find it just as economical to travel outside of Brazil as it is to travel to the Amazon from São Paulo or Rio de Janeiro. Resource managers will need to collaborate with local tourism administrations and private agencies to market the amenities of their specific settings.

The Tapajós has been somewhat successful at meeting visitor's expectations despite the lack of infrastructure and difficult access, Tapajós visitors might be looking for an authentic experience in the Amazon. In contrary, the first contact with the urban environment in Novo Airão might either disappoint those looking for authenticity or creates high expectations on the quality of services and facilities. This will be a challenge for ICMBio to overcome, as most resource managers have not focused on seeking a 
competitive edge in attracting visitors. Tour operators can assist in this endeavor, as noted in recent research (Alegre \& Sard, 2017; Picazo \& Moreno-Gil, 2018).

\section{CONCLUSIONS}

This study aimed at understanding the profile of users of two conservation units in the Brazilian Amazon with the intent of informing decision-making regarding tourism. This effort has shown that quite a lot of work must be done in terms of recreation research in protected areas in the Brazilian Amazon. The region has all the natural attributes that can be of interest to a variety of visitors. Contrary to its neighboring countries, Brazil still struggles on using Amazon's full potential to attract visitors to generate revenue. The financial outcome of having visitors in these areas can support local economy. In a long term, ideally, conservation units can contribute to national economy.

Since visitors primarily visit the Tapajós National Forest and the Anavilhanas National Park to experience nature and culture managers should emphasize and include specific activities to promote cultural tourism in the two conservation units. Also, access was found to be an important issue in these areas. Before doing it so, investments on access, especially road maintenance, should be made.

Strengthening partnerships is fundamental for gaining extra help on data collection and analysis. It is worth mentioning that the efforts for monitoring visitor use is not valid until applied to management decisions.

Finally, it is important to realize that the relationship of humans with nature is ever changing and the rise of new outdoor recreation trends is inevitable. Protected areas need to keep up with visitor's demands and make 
wise decisions for promoting conservation and enhancing the quality of the visits. Having visitor use data allows resource managers to make sciencebased decisions regarding tourism infrastructure and services.

\section{REFERENCES}

Alegre, J., \& Sard, M. (2017). Price strategies by German and British tour operators in Mallorca. Journal of Hospitality and Tourism Management, 33, 93102.

Arnberger, A., Ebenberger, M., Schneider, I.E. Cottrell, S., Schlveter, A.C., Ruschkowski, E., Venette, R.C., Snyder, S.A. \& Gobster, P.H. (2018). Visitor Preferences for Visual in Bark Beetle-Impacted Forest Recreation Settings in the United States and Germany. Environmental Management, 61 (2), 209-223. doi: https://doi.org/10.1007/s00267-017-0975-4

Alves, L.C.P.S., Machado, C.J.S., Vilani, R.M., Vidal, M.D., Andriolo, A. \& Azevedo, A. F. (2013). As atividades turísticas baseadas na alimentação artificial de botos-da-Amazônia (Inia geoffrensis) e a legislação ambiental brasileira. Desenvolvimento e Meio Ambiente, 28(2), 89-106.

Berg, B., \& Lune, H. (2004). Qualitative research methods for the social sciences. Pearson: Boston.

Boley, B.B., McGhee, N.C. \& Hammett, A.L. (2017). Importance-performance analysis (IPA) of sustainable tourism initiatives: The resident perspective. Tourism Management, 58, 66-77.

Boza, M. (1993). Conservation in Action: Past, Present, and Future of the National Park System of Costa Rica. Conservation Biology, 7(2), 239-247.

Burns, R.C. \& Moreira. J. C. (2013). Visitor management in Brazil's protected areas: Benchmarking for best practice in resource management. The George Wright Forum, 30, 163-170.

Burns, R.C. \& Moreira. J. C. (2017). Anavilhanas National Park Recreation Survey. Final Report, Submitted to USDA Forest Service: Washington.

Burns, R.C. \& Graefe, A. (2007). Constraints to outdoor recreation in Pacific Northwest national forests: Exploring perceptions of respondents whose households include persons with disabilities. Journal of Leisure Research, 39(1), 156-181. 
Burns, R.C. \& Robinson, K. (2017). Oregon's aging population: Relationships between facilities, services, participation, and socio-demographics in outdoor recreation settings. Journal of Park and Recreation Administration 35(4), 13-23.

Castro, E. V., Souza T. B. \& Thapa, B. (2015). Determinants of tourism attractiveness in the National Parks of Brazil. Parks, 21 (2), 51-62.

Cervinka, R., Höltge, J., Pirgie, L., Schwab, M., Sudkamp, J., Haluza, D., Arnberger, A., Eder, R., \& Ebenberger, M. (2014). Green Public Health Benefits of Woodlands on Human Health and Well-being [Zur Gesundheitswirkung von Waldlandschaften]. Vienna, Austria: Bundesforschungszentrum für Wald (BFW).

Constituição da República Federativa do Brasil de 1988. (1988). Brasília.

Recuperado em 10 out. 2017, de http://www2.camara.leg.br/legin/fed/consti/1988/constituicao-1988-5-outubro-1988322142-publicacaooriginal-1-pl.html

Drummond, J. A. L. (2016). From Randomness to Planning: the 1979 Plan for Brazilian National Parks. In Fiege, M., Jared, O \& Hawkins, A. (Orgs.), National Parks beyond the Nation: 'Global Perspectives on 'America's Best Idea'. (1a ed., pp. 210-234).Oklahoma (EUA): University of Oklahoma Press.

Eagles, P. (2016). Foreword. In S. Mccool, \& K. Bosak (Orgs.). Reframing Sustainable Tourism. (1 a ed., pp 5-7). New York: Springer Publishing.

English. D. B. K., Kocis. S. M., Zarnoch. S. J. \& Arnold, J. R. (2002). Forest Service national visitor use monitoring process: research method documentation. NC: U.S. Department of Agriculture, Forest Service, Southern Research Station.

Garcia, L. V. M. (2015). Cachoeira da Mariquinha: Impactos e potencialidades do uso público no Parque Nacional dos Campos Gerais PR. (Dissertação de Mestrado). Universidade Estadual de Ponta Grossa, Ponta Grossa, PR, Brasil.

ICMBio. (2016). Aumenta número de visitantes em Unidade de Conservação. Available at <http://www.icmbio.gov.br/portal/ultimas-noticias/4destaques/7579-numero-de-visitantes-nas-ucs-federais-aumenta-320 >. Acessed in: 05th feb. 2018.

ICMBio (2018). Mais de 1,7 milhão de pessoas visitaram o Parque do Iguaçu. Available at <http://www.icmbio.gov.br/portal/ultimas-noticias/20-geral/9389-mais-de-1-7-milhaode-pessoas-visitaram-o-parque-do-iguacu >. Acessed in: 25 feb. 2018. 
Jamal, T.B. \& Getz, D. (1995). Collaboration theory and community tourism planning. Annals of Tourism Research, 22(1), 186-204.

Jesus, V. R. (2010). Developing sustainable tourism in the Amazon rainforest of Brazil - premises, actions, challenges. Worldwide Hospitality and Tourism Themes, 2(2),144-152.

Joppe, M. (1996). Sustainable community tourism development revisited. Tourism Management, 17(7), 475-479.

Kinker, S. (2002). Ecoturismo e conservação da natureza em parques nacionais. São Paulo: Papirus.

Lee, T.H. \& Jan, F. H. (2018). Can community-based tourism contribute to sustainable development? Evidence from residents' perceptions of the sustainability. Tourism Management, 70(1), 368-380.

Lei n. 9.985, de 18 de julho de 2000. Regulamenta o art. 225, § 1으, incisos I, II, III e VII da Constituição Federal, institui o Sistema Nacional de Unidades de Conservação da Natureza e dá outras providências. Brasília, DF. Recuperado em 24 novembro, 2016, de http://www.mma.gov.br/estruturas/sbf_corredores/_arquivos/snuc.pdf

Lew, A. A. \& McKercher, B. (2002). Trip Destinations, Gateways and Itineraries: The Example of Hong Kong. Tourism Management, 23(6), 609-621.

Likert, R. (1932). A technique for the measurement of atitudes. Archives of psicology, 22(140), 5-55.

Marion, J. L. \& Farrell, T. A. (2002). Management practices that concentrate visitor activities: camping impact management at Isle Royale National Park, USA. Journal of Environmental Management, 66(2), 201-212.

Medeiros, R. (2006). Evolução das tipologias e categorias de áreas protegidas no Brasil. Ambiente \& Sociedade, 9(1), 41-63.

Medeiros, R., \& Young, C.E.F. (2011). Contribuição das Unidades de Conservação brasileiras para a economia nacional: Relatório Final. Brasília: UNEP-WCMC.

Ministério do Meio Ambiente. (2018). Cadastro Nacional de Unidades de Conservação. Retrieved from http://www.mma.gov.br/images/arquivo/80112/CNUC_JUL17\%20\%20C_Bio.pdf >. Acessed in: 31 jan. 2018. 
Pádua, M. T. J. (1978). Categorias de Unidades de Conservação - Objetivos de Manejo. Boletim FBCN, 13, 78-84.

Peres, C. A. \& Terborgh, J. W. (1995). Las Reservas Naturales Amazónicas: un análisis del estado relativo de protección de las unidades de conservación existentes y del criterio de diseño para el future. Conservation Biology 9(1), 3446.

Picazo, P. \& Moreno-Gil, S. (2018). Price strategies by German and British tour operators in Mallorca. Journal of Hospitality and Tourism Management, 35, 1728.

Pimentel, D. S. \& Magro, T. C. (2011). Múltiplos olhares, muitas imagens o manejo de parques com base na complexidade social. GEOgrafia (UFF), 13 (26), 92-113.

Rodrigues de Jesus, V. (2010). Developing sustainable tourism in the Amazon rainforest of Brazil - premises, actions, challenges. Worldwide Hospitality and Tourism Themes, 2, 144-152. doi:10.1108/17554211011037831

Romagnoli, F. C. (2009). Interpretação ambiental e envolvimento comunitário: ecoturismo como ferramenta para a preservação do botovermelho, Inia geoffrensis. (Dissertação de mestrado). Instituto Nacional de Pesquisas da Amazônia, Manaus, AM, Brasil.

Santos, G. E., Ramos, V. \& Rey-Maquieira J. (2014). Length of stay at multiple destinations of tourism trips in Brazil. Journal of Travel Research, 54 (6), 788-800.

Serviço Florestal Brasileiro. (2013). Florestas do Brasil em resumo - 2013: dados de 2007-2012. Serviço Florestal Brasileiro: Brasília.

Souza, T. B. (2016). Recreation classification, tourism demand and economic impacts analyses of the federal protected areas in Brazil. (Tese de doutorado). University of Florida, Gainesville, FL, Estados Unidos.

Tanner, J. B., Thomas, P., Sills, E. O. \& Silva, S.S. (2017). The potential demand for ecotourism in the Tapajós National Forest, Pará, Brazil, 1997. FPEl Working Paper, 62, 1-54.

Tiefenbacher, J. P., Day, F. A. \& Walton, J. A. (2000). Attributes of repeat visitors to small tourist-oriented communities. The Social Science Journal, 37 (2), 299-308. 
Van Niekerk, M. (2014). Advocating community participation and integrated tourism development planning in local destinations: The case of South Africa. Journal of Destination Marketing and Management, 3(2), 82-84.

Vidal, M. D., Santos, P.M.C., Jesus, J. S., Alves, L.C.P.S. \& Chaves, M.P.S.R.; (2017). Ordenamento participativo do turismo com botos no Parque Nacional de Anavilhanas, Amazonas, Brasil. Boletim Museu Paraense Emilio Goeldi, 12(1), 23-36.

Williams, F. (2016, January). The Power of Parks. National Geographic, 229(1), 54-67.

White, R. (1985). American Environmental History: The Development of a New Historical Field. Available at $<$ http://www.jstor.org/stable/3639634? seq=1 \& cid=pdfreference\#fndtn-references tab contents >. Acessed in 24 feb. 2018.

\begin{tabular}{|l|l|}
\hline Author 1 - Robert Clyde Burns & $\begin{array}{l}\text { Co-wrote the paper, based on the } \\
\text { reports and the thesis developed by } \\
\text { Lidiane Castro Gregory. Coordinated } \\
\text { the research. }\end{array}$ \\
\hline Author 2 - Lidiane Castro Gregory & $\begin{array}{l}\text { Collected the data and analyzed } \\
\text { data, developed tables, wrote a } \\
\text { draft document. Coordinated the } \\
\text { field team. }\end{array}$ \\
\hline Author 3 - Jasmine Cardozo Moreira & $\begin{array}{l}\text { Developed methodology, survey } \\
\text { instrument and co-wrote the paper. }\end{array}$ \\
\hline
\end{tabular}


A profile of visitors to Brazil Amazon Protected Areas: Anavilhanas National Park (Amazonas) and Tapajós National Forest (Pará) 
